\title{
Research and Progress on the Mechanism of Iron Transfer and Accumulation in Rice Grains
}

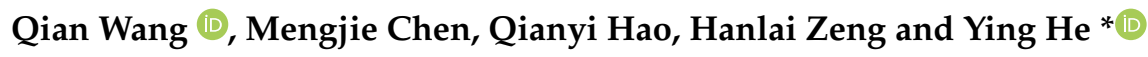

check for updates

Citation: Wang, Q.; Chen, M.; Hao, Q.; Zeng, H.; He, Y. Research and Progress on the Mechanism of Iron Transfer and Accumulation in Rice Grains. Plants 2021, 10, 2610. https://doi.org/10.3390/plants 10122610

Academic Editors: Dimitris Bouranis, Freddy Mora-Poblete, Viktor Korzun and Antônio Teixeira do Amaral Junior

Received: 29 September 2021 Accepted: 26 November 2021 Published: 28 November 2021

Publisher's Note: MDPI stays neutral with regard to jurisdictional claims in published maps and institutional affiliations.

Copyright: (C) 2021 by the authors. Licensee MDPI, Basel, Switzerland. This article is an open access article distributed under the terms and conditions of the Creative Commons Attribution (CC BY) license (https:// creativecommons.org/licenses/by/ $4.0 /)$.
MOA Key Laboratory of Crop Ecophysiology and Farming System in the Middle Reaches of the Yangtze River, College of Plant Science and Technology, Huazhong Agricultural University, Wuhan 430070, China; SamWang@webmail.hzau.edu.cn (Q.W.); chenmj@webmail.hzau.edu.cn (M.C.); haoqy@webmail.hzau.edu.cn (Q.H.); zenghl@mail.hzau.edu.cn (H.Z.)

* Correspondence: yinghe@mail.hzau.edu.cn

\begin{abstract}
Iron (Fe) is one of the most important micronutrients for organisms. Currently, Fe deficiency is a growing nutritional problem and is becoming a serious threat to human health worldwide. A method that could help alleviate this "hidden hunger" is increasing the bioavailable Fe concentrations in edible tissues of major food crops. Therefore, understanding the molecular mechanisms of Fe accumulation in different crop tissues will help to develop crops with higher Fe nutritional values. Biofortification significantly increases the concentration of Fe in crops. This paper considers the important food crop of rice (Oryza sativa L.) as an example and highlights recent research advances on the molecular mechanisms of Fe uptake and allogeneic uptake in different tissues of rice. In addition, different approaches to the biofortification of Fe nutrition in rice and their outcomes are described and discussed. To address the problems that occur during the development and application of improving nutritional $\mathrm{Fe}$ in rice, technical strategies and long-term solutions are also proposed as a reference for the future improvement of staple food nutrition with micronutrients.
\end{abstract}

Keywords: rice grain; iron uptake; transport and accumulate; nutritional strengthen; genome editing techniques

\section{Introduction}

Micronutrients play a vital role in activities of life and human health. The lack of micronutrients, also called "hidden hunger", is an increasingly serious and global health problem that humans face. As one of the important micronutrients, iron (Fe) deficiency is also prevalent in worldwide populations. Anaemia affects one-third of the world's population with iron deficiency anaemia (IDA) being the top cause. IDA is highly prevalent in preschool children ( $<5$ years), women of reproductive age and pregnant women, with prevalence rates reaching up to $39.8 \%, 29.6 \%$ and $36.5 \%$, respectively [1]. Anaemia is more largely caused by the difference in the degree of social and economic development of the countries, but the specific cause is the insufficient daily dietary intake of nutritional trace elements. Prevention strategies and mitigation measures of adding Fe supplements and optimizing dietary structure have been utilized around the world in the last two decades but have not significantly improved Fe nutrition levels for the global population [2]. Improving the endogenous Fe concentration of staple food should be a main goal for developing countries as a sustainable strategy because dietary components as sources of iron have only resulted in limited improvement [3].

Rice (Oryza sativa L.) is an important cereal crop and a staple energy source for half the global population [4]. Based on the extensive consumption and wide variability of the grain, enhancing its endogenous Fe concentration or optimizing the Fe storage form, should be an effective way to increase not only the nutritional Fe supply of the diet but also its biological utilization efficiency. These methods might be basic and feasible ways to alleviate global Fe deficiency, particularly in developing countries [3]. Hence, this study 
investigates differences in Fe concentrations and the food safety range of different genotype rice varieties, describes the mechanisms of Fe uptake, distribution, and accumulation from soil to seed, summarizes the progress of biological strengthening for rice grain Fe in the past two decades, and offers a new direction to focus.

\section{Physiological Function of Fe and Its Nutritional Requirements in Organisms}

\subsection{Physiological Function of Fe in Organisms}

Fe is one of the essential elements for the activities of life. Biological endogenous Fe often exists in multiple redox forms and is widely involved in multiple physiological processes, including cytochrome and ferritin formations, electron transfer processes, and redox reactions [5]. During plant growth, Fe deficiency usually reduces leaf chlorophyll concentration and photosynthesis, leading to the leaves losing their green colour, yellowing, or gaining discolouration. In severe cases, the root epidermis can become necrotic, which can lead to stunted growth or even death. Although the Earth's crust is relatively rich in Fe (Fe composes approximately $5 \%$ of the crust), approximately $25 \sim 40 \%$ of the world's arable land is still severely deficient in effective Fe. This is especially apparent in alkaline or neutral arable land in which Fe deficiency is particularly pronounced and Fe is present in an oxidized state, which is not conducive to the use and uptake by plants. When crops are grown under such conditions, their normal growth and development are restricted, resulting in reduced yields and lower quality, which causes serious losses to agricultural production [5].

For animals and humans, Fe is a functional component of haemoglobin, myoglobin, and oxidoreductase, which is involved in numerous physiological processes to ensure the normal activities of life can occur, such as oxygen transport, exchange, and respiration. IDA is caused by a lack of Fe intake in humans, resulting in cognitive and immunity decreases in special populations and an increased risk of maternal mortality during perinatal periods [6]. Three effective strategies of mineral supplements, food fortification, and nutrient enrichment are proposed to combat Fe deficiency. The implementation of the first two strategies is complex and not very affordable in developing and less developed countries but the third strategy is expected to be an effective and lasting approach [7]. Cereal crops are the main source of Fe intake for humans and animals, and consuming more Fe-rich food crops can supply more Fe to alleviate the problem of Fe deficiency. Especially in Asian countries where $90 \%$ of the world's rice is produced and consumed [8]. Despite the high level of Fe in cultivated soil or rice grains, the effectiveness and rate of biological utilization of Fe from rice is low. On the one hand, rice is traditionally cooked after milling and polishing, reducing the nutritional value because of the removal of the Fe-rich bran and embryo, with only the endosperm remaining, On the other hand, the main Fe-chelation form of rice is not well-absorbed by human intestines [9]. Therefore, the Fe level in food crops and rice grains in particular is directly related to the crop nutritional level and health status of humans. Increasing the effectiveness and available Fe in rice grains is a key strategy for developing countries to relieve Fe deficiency in their populations.

\subsection{Range Variation of Fe Concentration in Rice Grains and Demand of Fe Concentration for Human}

Grain Fe concentration is greatly affected by different rice genotypes. The grain Fe concentration of brown rice was investigated from 113 major cultivated rice varieties in China and the results revealed a variation range of $12.16 \sim 53.62 \mathrm{mg} \mathrm{kg}^{-1}$ and a mean value of $24.59 \mathrm{mg} \mathrm{kg}^{-1}$ [10]. In polished rice grain, the Fe concentrations in 598 rice resources and breeding materials worldwide were only $0.86 \sim 11.34 \mathrm{mg} \mathrm{kg}^{-1}$ [11]. Lu et al. (2013) found brown rice includes bran, endosperm, and embryos, which have significant tissuespecific differences in the micronutrient levels, such as the Fe concentration. Rice bran usually contains large amounts of micronutrients with Fe levels up to $86 \sim 430 \mathrm{mg} \mathrm{kg}^{-1}$. However, the Fe concentrations of brown and polished rice differ from $2 \sim 52 \mathrm{mg} \mathrm{kg}^{-1}$ and $2 \sim 28 \mathrm{mg} \mathrm{kg}^{-1}$, respectively [12]. 
For humans, the average daily Fe requirements are different based on individual ages, genders, and weights, with a range of $8 \sim 18 \mathrm{mg} \mathrm{day}^{-1}$. Pregnant women in particular have a Fe requirement of over $30 \mathrm{mg} \mathrm{day}^{-1}$ [13]. Moreover, excessive micronutrient intake can be detrimental to human health; therefore, the proposed maximum limit of Fe in grains is $50 \mathrm{mg} \mathrm{kg}^{-1}$ [14]. Considering the daily consumption of rice, researchers have proposed that the basic standard of the nutritional Fe level in rice grain should reach $15 \mathrm{mg} \mathrm{kg}^{-1}$ [15]. There is still a gap between the human nutritional requirements and the improvement of crops or staple food nutrition despite the great progress that has occurred in crop nutritional biological reinforcement research [2]. For the main planted rice varieties, the endosperm Fe level and utilization should be emphasized, which has potential for nutritional improvement.

\section{Fe Absorption and Transport Mechanism in Rice Plants}

\subsection{Absorption Mechanism of Fe into Rice Roots}

To adapt to different soil or environmental conditions, plants have developed two different strategies to secure Fe in roots, namely, the reducing strategy (I) and the chelating strategy (II). Non-grass plants adapt to strategy I, in which the soil pH is directly reduced and the available $\mathrm{Fe}^{3+}$ is increased by protons flowing from the root cell to the rhizosphere. Then, ferric chelate reductase (FRO) on the root surface catalyzes the reduction of surface $\mathrm{Fe}^{3+}$ into $\mathrm{Fe}^{2+}$. Finally, $\mathrm{Fe}^{2+}$ is directly transported to the root cell by iron-regulated transporter 1 or iron-regulated transporter 2 (IRT1/IRT2). However, in the Gramineae adaptation strategy II, the root cells exocytose the pytosiderophore (PS), which chelates with $\mathrm{Fe}^{3+}$ in the soil to form Fe-PS. Then, Fe-PS is transported to the root via the yellow stripe-like (YL/YSL) transporter family and enters the root cell $[16,17]$.

The above two absorption mechanisms have been demonstrated in rice. However, it has been reported that FRO has very low activity on the surface of rice roots. Because of rice roots exposure in anaerobic conditions, $\mathrm{Fe}^{2+}$ is abundant and can be absorbed directly without activation of FRO. The mechanism by which soil $\mathrm{Fe}^{2+}$ is directly absorbed is partially mediated by the Fe transporter OsIRT1 and OsIRT2 that is anchored in the rice root cell membrane $[18,19]$. In addition, the natural resistance-associated macrophage protein (NRAMP) family members OsNRAMP1 and OsNRAMP5 positively regulate rhizosphere $\mathrm{Fe}^{2+}$ absorption in rice (Figure 1A) [20,21]. Furthermore, the root phenolic outflow allows the occurrence of insoluble Fe in solution from the soil. For example, rice root efflux of protocatechuic acid (PCA) into the soil can increase Fe availability to assist root Fe absorption using strategy I (Figure 1A) [22,23].

Current mechanistic studies have indicated that the most important chelator for Fe is mugineic acid (MA) in rice. The MA family is synthesized through a conserved pathway that was originally from S-adenosine methionine, in which the three synthases are nicotianamine synthase (NAS), nicotianamine aminotransferase (NAAT) and deoxymugineic acid synthase (DMAS). DMAS mediates deoxymugineic acid (DMA) synthesis and is further hydroxylated to MA (Figure 1A) [24-26]. In rice roots, only DMA is secreted into the rhizosphere to bind with rhizosphere $\mathrm{Fe}^{3+}$ and form the $\mathrm{Fe}$ (III)-DMA complex, which is then transported via MAs efflux transporter 1 (OsTOM1). In addition, the Fe(III)-DMA form can be transported to root tissue with the assistance of YSL family members OsYSL15 and OsYSL16 $[27,28]$. Nicotianamine (NA), an intermediate product of MA synthesis, also combines with $\mathrm{Fe}^{2+}$ to form $\mathrm{Fe}(\mathrm{II})-\mathrm{NA}$. Subsequently, the Fe-chelated form is transferred to other desired Fe tissues and is involved in several activities, such as photosynthetic and electron transport chain activity in leaves, is stored reproductive organs, and participates in seed development (Figure 1A) [29]. 


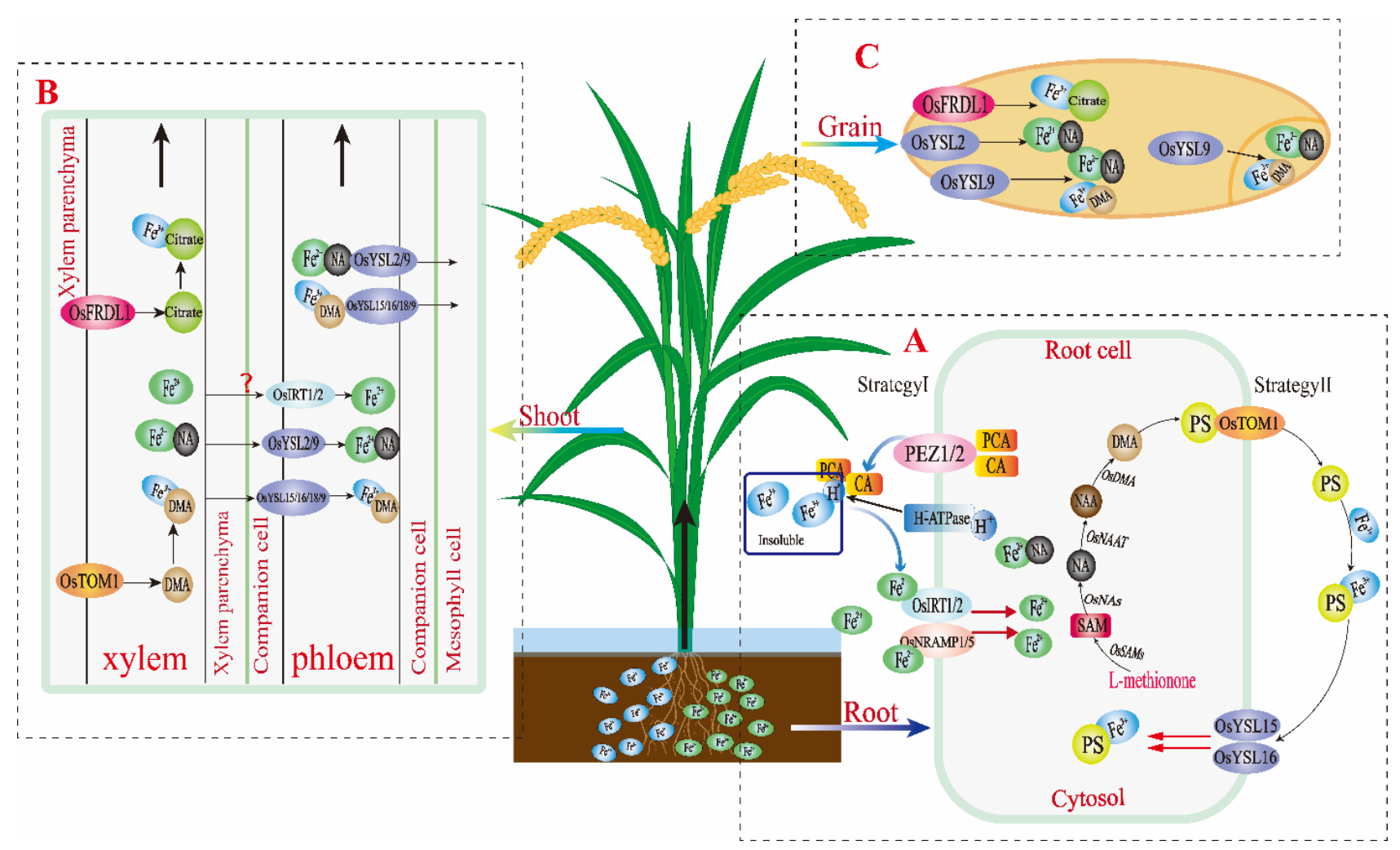

Figure 1. Schematic diagram for Fe uptake mechanisms in roots through strategy I, strategy II, Fe-transport from roots to shoots and grains in rice plant. Absorption mechanism of Fe into rice roots (A). Fe-transport mechanism from root to shoot (B) and grain $(\mathbf{C})$ in rice plants.

\subsection{Fe Transport Mechanism in Rice Plants}

The upward movement of Fe ions from root cytosol to young branches, leaves, and other tissues through xylem and phloem, which relies mainly on the action of root pressure, transpiration pull, and transporter proteins. Usually, DMA and NA are required for chelated Fe transport in rice, which thereby avoids excessive Fe ions precipitation, reactive oxygen species caused by Fenton reaction to damage cells [30,31]. In addition, some other chelating agents are involved in Fe transport between rice tissues, such as citrate NA and DMA. The form of Fe(III)-citrate is mostly actively transported through loading and the multidrug and toxin efflux family (MATE) and protein ferric reductase defective like 1 (OsFRDL1) (Figure 1B,C) [32,33]. In particular, in rice phloem, the nonprotein peptides of NA and DMA assist in Fe active transport with Fe(II)-NA and Fe(II)-DMA chelation via the YSL specific transporters between tissues. Whether the IRT transporter is involved in the transport of $\mathrm{Fe}^{2+}$ is still controversial and needs further study (Figure 1B).

The YSL family consists of 18 members in rice, of which OsYSL15 and OsYSL16 have been identified to participate in the rhizosphere absorption of Fe and phloem Fe(III)-DMA transport [28,34]. OsYSL18 is involved in Fe(III)-DMA transport in reproductive organs, crown root epidermis, the phloem of leaf sheath and accompanying cells (Figure 1B) [35]. Notably, OsYSL2 is specifically involved in Fe(II)-NA transport into rice seeds $[30,36]$. Recently, it was found that both Fe(II)-NA and Fe(III)-DMA can be transported into rice grains via OsYSL9 and are involved in grain Fe distribution and transport, especially from endosperms to embryos (Figure 1C) [37]. Studies of chelators and transporters enrich our understanding of the mechanism of Fe accumulation and homeostasis in rice plants.

At present, there is still a gap in the understanding of the Fe absorption and transport mechanisms in rice, especially their transport mechanisms such as the possible chelator types, individual Fe transport quantities and contributions, and their tissue-specific 
functions in different transport mechanisms. Therefore, the molecular mechanisms of Fe transport, accumulation, and redistribution within rice tissues need to be studied further.

\subsection{Accumulation Form and Distribution Characteristics of Fe in Rice Grain}

The development of technology allows for Fe distribution to be more clearly understood in plants. Perls Prussian blue stain has revealed that Fe was unevenly distributed in rice grains and most of the Fe was in the embryo, the secondary Fe was in the pericarp and aleurone layers and the least amount of Fe was in the endosperm. The Fe distribution was also disproportionate, particularly in embryos, with the strongest distribution in the shield, the middle distribution in the germ sheath and the weakest distribution in the root sheath [38]. The refined distribution of grain minerals has been reported through synchrotron based on X-ray and fluorescence techniques, and most of the grain Fe was concentrated in the rice husk and bran cell layers [12,39], characterizing the Fe distribution in rice grain using inductively coupled plasma mass spectrometry, which was bran $>$ shell $>$ whole-grain $>$ brown rice $>$ polished rice [40].

Fe homeostasis is tightly regulated throughout plant growth. As mentioned above, Fe is mostly absorbed and transported by binding to various chelators for plants. Simultaneously, these chelators, including organic acids (phytic acid, citrate and malate), amino acids (histidine), inorganic ions $\left(\mathrm{SO}_{4}{ }^{2-}\right.$ and $\left.\mathrm{HCO}_{3}{ }^{-}\right)$, short peptides (DMA and NA), and ferritin (FER), also chelate endogenous Fe for accumulation and storage in plant tissues. Among these chelators, the main chelators in rice are NA, DMA, FER, and citrate [41,42]. By phosphorus $(\mathrm{P})$ and Fe tracers, studies have shown that grain Fe is mostly stored in the protein storage vacuoles (PSVs) of rice grains by binding to phytic acid (PA) [43]. Moreover, it is believed that FER is the main Fe storage protein not only in plants but also in animals, which can store up to $4500 \mathrm{Fe}$ atoms and can also be released with the bioavailable form of $\mathrm{Fe}^{3+}$ [44]. In general, these FERs are located in nutrient plant organs, such as leaf vacuoles and chloroplasts. There are two FER genes, OsFER1 and OsFER2, in the genome of rice, and neither of them are detected in normal developing or mature seeds. Rice seed OsFER can be induced by exogenous Fe during its germination under dark conditions, suggesting that the main role of OsFER in seed is to protect tissue against free ferritin-mediated oxidative stress instead of Fe storage [45]. When OsFER is endosperm-specifically expressed through the promoter regulation of globulin or glutelin, the rice endosperm Fe concentration is still increased by 2.0 3.7-fold [46]. Notably, Kyriacou et al. (2014) performed a comparative analysis of grain Fe accumulation in wild-type and reinforced rice and found that numerous $\mathrm{Fe}(\mathrm{II})-\mathrm{NA}$ and Fe(III)-DMA accumulated in the aleurone layer instead of the Fe-PA form. At present, little is known about the specific form, contribution rate, chelate type, and composition of Fe location and accumulation, especially in rice grains [47]. Therefore, it is necessary to further study and clarify the mechanism of Fe enrichment in rice and provide a theoretical basis for a new molecular strategy to enhance the amount of bioavailable Fe in staple food.

\section{Interrelationship and Balance between Fe and Other Elements in Rice \\ 4.1. Interrelationship and Balance between Fe and Other Metal Elements in Rice}

A balance between endogenous metal elements is essential for maintaining normal metabolic activities in plants. In particular, various metal elements must be strictly supervised and maintained to ensure their optimal concentrations, maintain their physiological functions and avoid oxidative damage that results from their excessive accumulation. It has been reported that different divalent metal ions could compete and interact, which affected their forms or contents in plants [48,49]. For example, zinc (Zn), manganese (Mn), and cadmium $(\mathrm{Cd})$ generally share an absorption mechanism with Fe, which commonly formats and regulates the homeostasis of endogenous metal elements in plants.

As mentioned above for the two mechanisms of Fe absorption in the soil-source $\mathrm{Fe}^{2+}$ and $\mathrm{Fe}^{3+}$, these processes and homeostasis are also affected by other metal cations, such as $\mathrm{Zn}^{2+}, \mathrm{Mn}^{2+}$, and $\mathrm{Cd}^{2+}[50]$. Metal-transport membrane systems can transport all kinds of 
metal cations, which may be a key aspect of their competition. For example, IRT1/IRT2 belongs to the zinc-/iron-regulated transporter-like protein (ZIP) family, mediating multiple metal transport of $\mathrm{Fe}^{2+}, \mathrm{Zn}^{2+}, \mathrm{Mn}^{2+}$ and $\mathrm{Cd}^{2+}$ [51]. In rice, OsIRT1 and OsIRT2 are associated with the absorption of bivalent metal ions, and the tissue Fe contents can increase via OsIRT1 overexpressing plants, but also promote $\mathrm{Zn}$ or $\mathrm{Cd}$ accumulation in roots and aboveground tissues [52]. Furthermore, both the OsZIP1-4 of ZIP family and OsHMA2 of Heavy Metal Atpase (HMA) family can transport bivalent $\mathrm{Fe}^{2+}$ and $\mathrm{Zn}^{2+}$; OsNRAMP1 and OsNRAMP5 of the NRAMP family can also transport different metal ions of the same valence state, such as $\mathrm{Fe}^{2+}, \mathrm{Mn}^{2+}$ and $\mathrm{Cd}^{2+}[53,54]$. In this pathway, important chelates, DMA and NA, are involved in the transport of other metal ions such as $\mathrm{Zn2}+, \mathrm{Mn} 2+$ and $\mathrm{Cu} 2+$ in addition to $\mathrm{Fe}^{3+}$ and $\mathrm{Fe}^{2+}$ [55]. The overexpression of homologous or heterologous NAS in rice plant significantly increases not only the Fe contents but also the $\mathrm{Zn}, \mathrm{Cu}$, and Mn contents in transgenic plants [9,56-61]. Accordingly, there is competition or synergy between the absorption and transport of Fe and other metal elements, including $\mathrm{Zn}, \mathrm{Mn}$, $\mathrm{Cu}$ and $\mathrm{Cd}$.

It seems possible that enhancing nutritional Fe concentration is accompanied by a reduction in certain heavy metal levels in cereal crops. Studies have shown that a method of applying Fe fertilizer can improve crop Fe concentration and effectively reduce the levels and toxicity of $\mathrm{Cd}$ to some extent. This effect can be explained by the competition of $\mathrm{Fe}^{2+}$ and $\mathrm{Cd}^{2+}$ for the same binding site and transport system on root surface cells, leading to a trade-off between the absorption of the two metals [62-64]. On the other hand, $\mathrm{Fe}^{2+}$ is an important cofactor of antioxidant enzymes, and plant oxidation resistance significantly improves with the increase and improvement in antioxidant enzyme upregulation in plants, forming a protective barrier against $\mathrm{Cd}$ toxicity [65]. In rice production, the application of $\mathrm{Fe}$ fertilizer also reduces lead $(\mathrm{Pb})$ induced cytotoxicity, which is similarly due to competition between $\mathrm{Fe}$ and $\mathrm{Pb}$ for transport proteins and long-distance transport-associated chelators, as mentioned above $[65,66]$.

Many studies on metal homeostasis have been carried out, but there are still gaps in our understanding of the overlapping mechanism of metal absorption and transport, physiological effects and coordination between metals and unknown molecules in their interaction network. Knowledge on the mechanisms of metal absorption, transport and homeostasis will intensify research efforts to better understand mechanical complexity and to provide a theoretical basis to improve crop nutrition reinforcement strategies.

\subsection{Interaction between Fe and $S$ and $P$ Elements}

Sulfur (S), one of the essential nutrients for plant growth processes, is a resistance factor against biotic and abiotic stresses. The homeostasis of various elements is continuously focused on in plants, especially for the interactions and linkages between Fe and S [67]. To respond to exogenous $\mathrm{S}$ nutrient supply, the Fe activation and translocation in plant can be up-regulated from plastid to roots or aboveground tissues, mainly due to the S-induced synthesis of substances, such as cysteine (Cys), glutathione (GSH) and phytochelatin (PC). The substances also provide the raw materials and substrates for the Fe chelations and transports synthesis. NA, a carrier molecule mentioned above, is one transport-related molecule for Fe chelation derived for Cys $[67,68]$. In rice, the previous study has been shown that an appropriate supply or application of the $S$ element could achieve an enhancement of Fe uptake and accumulation with the synergistic effects [69]. The molecular mechanism of the interaction between $S$ and Fe is still poorly understood, which needs focus on in the further.

Phosphorus, an essential macronutrient for crop growth, is widely known with the phosphate (Pi) form for uptake in plants. Fe can interact with $\mathrm{Pi}$ in the soil, growing medium, plant root surface. In the antagonistic manner of Pi and Fe interact, the Pi deficiency has been increased the Fe concentration in rice seedling shoots, while not affected in its roots [70-72]. It has been shown that the Fe intensification is attributed to the response of the Fe-responsive genes induced to the Pi deficiency under the P-deficient 
conditions for plants [73]. In other words, the Fe deficiency also contributed to the Pi accumulation in plants. The results of experiments with Pi- and Fe-treated Arabidopsis seedlings suggest that the effectiveness of Fe affects the response of lateral roots to Pi deficiency $[71,74]$.

Recently, studies on the molecular basis of the interaction between Pi and Fe in plants have made outstanding progress. Under Pi deficiency in plants, the core transcription factors of the phosphate starvation response, PHOSPHATE RESPONSE 1 (PHR1) and PHR1-LIKE 1 (PHL1), control the expression of the Pi transporter proteins, PHOSPHATE TRANSPORTER1 (PHT1) and PHOSPHATE1 (PHO1). Moreover, PHR1 and PHL1 act as the positive regulators of the transcription of Fe transporters FER1, NAS3, and YLS8 responsible for Fe homeostasis in plants [75,76]. On the other hand, some other transcription factors involved in the interaction mechanism between Pi and Fe, including LOW PHOSPHATE ROOT1 (LPR1), PHOSPHATE DEFICIENCY RESPONSE2 (PDR2), as well as the SENSITIVE TO PROTON RHIZOTOX-ICITY1 (STOP1) and its target ALUMINIUM ACTIVATED MALATE TRANSPORTER 1 (ALMT1). For example, the Pi deficiency had induced a STOP1-modulated signaling cascade (PDR2-LPR1-STOP1-ALMT1) to promote the Fe accumulation in roots $[77,78]$. In addition, the Pi-dynamics changes had also induced Mitogen-activated protein kinase (MAPK)-mediated Pi sensing, signaling and responses in plants, whereas the Fe deficiency had reduced a MAPK6 activity to repress PHT1 family genes downstream of the WRKY75 transcription factor, suggesting that a mechanism in coordinating $\mathrm{Pi}$ and Fe nutrient responses [79]. In rice, although root growth is either enhanced or unaffected by low $\mathrm{Pi}$, at least one component of the signaling pathway controlling local Pi-deficiency responses (LPR ferroxidase) has been shown to affect Fe accumulation and Pi translocation. Additionally, the potential involvement of PHR1 in the Pi-Fe signaling crosstalk has been proposed [80]. A recent new study shows that the notable Hemerythrin motif-containing Interesting New Gene- and Zinc-finger proteins (HRZs) and PHRs, forming a mutually repressive module that could coordinate the Pi and Fe signaling and homeostasis [81]. However, the underlying mechanism of Pi-Fe signaling interactions centered on PHR is still much unknown and needs to be further explored. At the end of the plant growth cycle, Fe is stored by chelating with Pi mainly in the seed vacuoles, which seems to limit Fe absorption in the intestine from the perspective of the human diet [82]. Currently, the understanding of the Pi-Fe interaction and the underlying specific mechanism remains limited, for example, Pi-Fe signaling interactions centered on PHRs in rice. In conclusion, future studies need to focus on how the Fe accumulation is influenced by other nutrients and the molecular basis for coordinating the mechanisms of interaction and homeostasis, which will help to identify new members involved in the Fe uptake and transport and improve the Fe accumulation in crops.

\section{Strengthening Route of Micronutrient Fe Nutrition in Rice Grains}

One grain-nutrient strengthening strategy is to explore and study the increasing contents or bioavailability of grain micronutrient nutrition through genetic and agronomic pathways. In particular, strengthening micronutrient Fe nutrition in food crops can serve as a pathway of mitigation and/or provide a solution to worldwide Fe deficiency [3]. Currently, unprecedented progress in rice high-yield breeding has been achieved, which has regretfully led to the loss of certain excellent and ancient genetic traits. These traits are potentially useful regarding the goal of grain high nutrition, such as in breeding and improving Fe-enriched rice with diversification resources and genetic information. Over the past few decades, studies based on the molecular mechanism of Fe homeostasis in plants have also explored potential or effective strategies for grain Fe nutritional strengthening in rice. The current strategies include three reinforcing methods, traditional breeding methods, transgenic biotechnology and agronomic optimization, which are acceptable for crop grain nutrition strengthening [83]. 


\subsection{Strengthening Grain Fe Nutrition through Conventional Breeding Methods}

For centuries, desirable food crop traits have been chosen to be bred with desirable high-yield targets. Due to the complex and strict network regulation of grain Fe and other elements, the study of crop grain Fe biological reinforcement has progressed slowly [84]. Traditional breeding relies on the diversity of Fe-enriched phenotype genetic traits in crops as well as the development of genetic markers, but rice varieties with Fe-enriched characteristics are often old, endemic, and/or wild species, which have been gradually ignored and lost due to their low production [85]. The modern breeding focus has emphasized the infiltration of special ideal traits in wild breeds into modern crops [86].

Genomic-wide association analysis (GWAS) and quantitative trait locus localization (QTL) that is associated with grain nutritional quality can be specifically identified and localized in the crop genome. Among them, GWAS was able to assess the impact of different single-nucleotide polymorphisms (SNPs) in populations to identify their important roles and polymorphisms for specific genes, especially to facilitate individual gene identification for crop high-Fe grain targets. GWAS analysis of 144 multiparent advanced-generation reciprocal line rice has already identified certain Fe-enriched and steady-state genes, including the NA synthesis gene OsNAS3 and the vacuolar iron transporter (VIT) family gene OsVIT1 [87]. In addition, QTLs are also a powerful tool to study polygenic quantitative traits. Certainly, several QTLs that are associated with grain micronutrient enrichment, including Fe and $\mathrm{Zn}$, have been identified and localized in the rice genome using molecular markers [88-90]. Anuradha et al. (2012) identified 14 QTLs that are associated with the Fe and $\mathrm{Zn}$ concentration from a hybrid population, as well as 12 candidates for Fe and $\mathrm{Zn}$ homeostasis, such as OsYSL1 and OsMTP1 [91]. All of the different crop population sizes and types, different experimental designs or statistical methods and annual environments greatly affect the accuracy of QTL information; therefore, it is not possible to correspond and fully unified these results with the results of numerous studies. To elucidate specific genetic traits, it is necessary to integrate the QTL information data obtained from multiple experiments and project the date into the common atlas [92]. Due to the lack of corresponding genetic markers in the genome, QTLs generally correspond to large chromosomal regions. Combined GWAS and QTL analyses can help to refine chromosomal regions and identify specific genes.

\subsection{Agronomic Optimization to Improve Rice Grain Fe Concentration and Bioavailability}

Crop micronutrient reinforcement can be achieved by soil or leaf fertilization, particularly foliar fertilizer, which is recognized as a short-term solution to improve the utilization rate of fertilizer nutrients and to improve the nutritional status of crops. Genetically, crop engineered nutritional reinforcements may be more cost-effective in the long term, and current agronomic measures are more enforceable and are very effective in improving the mineral content of grain crops.

Mineral-enriched crop cultivation and planting are limited by the effective micronutrient quality of cultivated land. The effective Fe absorption and utilization from soil are also determined by the $\mathrm{pH}$ value and solubility of cultivated land [93]. For example, $\mathrm{Fe}$ generally exists as $\mathrm{Fe}^{3+}$ under dry land and oxidation conditions, maintaining and forming an insoluble Fe oxide/hydroxide form. In contrast, Fe usually exists as $\mathrm{Fe}^{2+}$ in anaerobic flooding conditions with better solubility and can more easily be absorbed and used. Therefore, soil fertilization that is based on reasonable Fe-source conditions is also an important factor to improve the Fe utilization rate in rice plants. Fageria et al. (2002) found that synthetic chelates are effective for applying Fe fertilizer in soil but are limited due to their high cost [94]. The $\mathrm{FeSO}_{4}$ solution is commonly applied, but it was noted that the inorganic solution applied was readily fixed into an insoluble form that was immersed in soil with low effects [95]. Nonetheless, soil/leaf Fe fertilization must be used as a complementary practice to improve crop Fe accumulation. For other trace elements, it has been found that leaf fertilization with $\mathrm{Zn}$ is very effective with increasing grain $\mathrm{Zn}$ under different soil conditions due to leaf $\mathrm{Zn}$ remobilization into grains during the rice grouting period [96]. The 
present study found that $\mathrm{H}^{+}$can be released by the rational application of organic fertilizer, reducing the $\mathrm{pH}$ value of soil and thus increasing the soil Fe solubility and availability. Compared to rhizosphere fertilization, the fertilization of leaf micro fertilizer has higher bioavailability and greater advantage in protecting the environment. Wang et al. (2020) applied the appropriate concentration of leaf Fe fertilizer, which not only improved rice yield and grain Fe concentration but also reduced the unavailable Fe-phytic acid level and grain $\mathrm{Cd}$ concentration by $29 \%$ [66]. In summary, rice grain Fe concentration is affected by multiple factors, and an effective, safe, and sustainable development strategy should be considered and carried out in combination with these factors.

In agricultural production, important agronomic methods have been widely explored to optimize the absorption of leaf fertilizer application and bioactivity for yield and quality improvements [97]. In contrast to the application of soil fertilizer, utilizing leaf fertilizer can directly and effectively increases crop micronutrient contents within a short term. Similar to the soil fertilization stage, spraying leaves with micro fertilizer during spike differentiation is more effective at improving the micronutrient content in rice grain. At the flowering stage, a zinc application of $0.5 \% w / v \mathrm{ZnSO}_{4}$ can significantly improve the grainzinc content in rice with a grain-zinc increase to two-fold [98]. Leaf spraying helps to avoid low Fe utilization in the soil, and considering the optimal spraying time is very important to effectively improve the grain Fe level. Some studies have compared four different forms of foliar Fe fertilizer, including $\mathrm{FeSO}_{4}$, EDTA-FeNa, DTPA-Fe, and HEDTA-Fe, and the studies showed that all of these forms could improve the grain Fe concentration and reduce the phytic acid content in rice endosperm, thus enhancing Fe bioavailability in rice grain. The foliar fertilizer of DTPA-Fe and $\mathrm{FeSO}_{4}$ was significantly better than that of the other two fertilizers [99]. It has also been shown that spraying leaves with Fe-amino acid (Fe-AA) chelate increases the rice grain Fe concentration, especially with the addition of $1 \%(w / v)$ Fe-NA, which resulted in a $32.5 \%$ increase [100]. Our group study has carried out in rice plants by spraying with different concentrations of $\mathrm{ZnSO}_{4} / \mathrm{FeSO}_{4}$ during the tillering and booting stages. The results have shown the spraying treatments should be successfully able to improve the photosynthesis efficiency and to enhance the grain pigment accumulation in the coloured rice [101,102]. Notably, foliar spraying with $\mathrm{FeSO}_{4}$ can also increase the grain Fe concentration by 2.5 1.3-fold in different rice varieties (unpublished data). Compared with soil fertilization, the application of microfertilizer has the advantage of economic, effective and sustainable development.

Nanoparticles (NPs) have a great potential in nanofertilizer applications involving agronomic optimization to improve the efficiency of agrochemicals to a greater extent $[103,104]$. In production, the application of $\mathrm{Fe}$-based nanoparticles can improve crop growth and ferritin accumulation. Li et al. (2021) found that low doses of zero-valent iron ( $\mathrm{ZVI})-/ \mathrm{Fe}_{3} \mathrm{O}_{4}-\mathrm{NPs}$ can be used as an alternative to conventional Fe fertilizer to ensure normal growth under Fe-deficient conditions [105]. The latest study has shown that the addition and application of Fe-nanoparticle fertilizer reduced the toxic accumulation of heavy metal elements, such as Cd and As, in rice plants [106,107]. In addition, some negative effects of Fe-based nanoparticles have been reported. For example, exogenous ZVI-NPs at a concentration of $500 \mathrm{mg} \mathrm{L}^{-1}$ can induce excess ROS accumulation, causing DNA damage and a reduction in the mitotic index in plant cells [108]. Nanofertilizers are controversial in such applications. Therefore, more research is needed to fully understand the impact of Fe-based nanomaterials before they can be safely applied in agricultural production.

\subsection{Genetic Engineering Technology Improves Fe Capacity in Rice Grain}

There is a limited range of genetic variation in the endospermic Fe levels in rice germplasms. Traditional breeding focuses on the excavation and breeding of Fe-rich rice resources. At present, nutritional grain Fe reinforcement has not yet been achieved in conventional staple food varieties. Using Fe absorption, transportation, and storage genetic engineering, modern breeding offers a complementary method to explore and create Fe-rich rice resources. Based on the progress in Fe absorption, transport, storage, 
regulation, and homeostasis, the current transgenic strategies and pathways for Fe bioreinforcement in crops are generalized [109-111]. Among the strategies, the more effective genetic bioreinforcement pathway includes (i) enhancing the absorption of soil-derived micronutrients, (ii) enhancing the transport of micronutrients into grains, (iii) increasing the accumulation of endosperm tissue-specific minerals, (iv) reducing the accumulation of antinutrient factors in grains, and (v) improving grain mineral bioavailability [84,112].

In the study of the Fe absorption mechanism, many of the genes involved have been identified in rice, among which target genes have also been used for rice genetic bioreinforcement. For Fe absorption in rice, overexpressing the transporter gene OsIRT1 induced a 1.7- and 1.1-fold increase in leaf and grain Fe concentrations, respectively [52]. It seems that it may be necessary for rice grain Fe reinforcement to both enhance its absorption and transport capacity, as well as strengthen the tissue-specific storage capacity of Fe. By transgenic technology, chloroplast-derived ferritin can be expressed in rice endosperm, and it is an efficient way to enhance the Fe storage capacity of rice endosperm. The tissuespecific promoter of globulin and glutelin drives ferritin expression in rice endosperm with a grain Fe increase of 2.0 to 3.7 times [46,56,113-115].

To improve Fe uptake and transport capacity in overall plants, certain strategies have been explored, including upregulating the induced Fe chelator synthesis pathway and regulating and optimizing inter-/intracellular transport and storage. The overexpression of NAS constitutive and PS synthesis genes in rice plants promotes the upregulation of Fe chelator synthesis NA and PS, which increases the grain Fe concentration in polished rice by two to four times $[25,26,59]$. The constitutive expression of the HvYS1 barley gene in rice under the controlled maize ubiquitin 1 (ubi-1) promoter moderately promotes Fe transport from roots to seeds with an increase in grain Fe accumulation [116]. The iron deficiencyspecific clone 3 (IDS3) gene derived from barley (Hordeum vulgare L.) can be expressed in rice, regulating the upregulation of Fe transport pathway genes and then increasing the grain Fe level by 1.4-fold in polished rice [117]. Rice plants with overexpression of OsYSL15 and OsYSL2 that is controlled by the promoter of the actin or sucrose transporter gene can have increased YSL expression level in various tissues, prompting a 1.2- to 4.0-fold increase in grain Fe concentration [27,30]. Senoura et al. (2017) found that OsYSL9 expression is depressed in rice plants through RNA interference (RNAi), which also impairs Fe transport from the endosperm to embryo, increasing the embryonic Fe concentration [37]. Thus, OsYSL9 is a good target gene for bioreinforcement. In rice, regulating Fe intracellular transport by decreasing OsVIT1 or OsVIT2 expression can promote inter-tissue Fe transport from flag leaves to grains, eventually increasing the endosperm Fe concentration [118-120]. Fe accumulation in polished rice can be altered by regulating the stem vacuolar mugineic acid transporter gene OsVMT, which is a vacuole membrane protein responsible for DMA transport into vacuoles. OsVMT knockdown can increase DMA in the cytosol to dissolve and chelate more $\mathrm{Fe}$, resulting in a grain $\mathrm{Fe}$ transport and accumulation increase by 1.0- to 2.1-fold compared to that of the wild-type [121].

In rice plants, Fe homeostasis regulators also indirectly influence the network of $\mathrm{Fe}$ transport and accumulation. For example, the transcription factor Fe-related transcription factor 2 (OsIRO2) is involved in regulating the biosynthesis of Fe chelate, MA, and the Fe-MA transport process. In calcium-based Fe-deficient soil, rice plants constitutively expressing OsIRO2 can still grow normally with a threefold increase in grain Fe concentration [122]. In addition, it has been reported that knockdown of negative regulator, zinc finger protein 1 and zinc finger protein 2 (OsHRZ1/OsHRZ2), can significantly promote grain Fe accumulation in rice [123].

Compared to the single-gene strategy, a gene-combination strategy related to effective Fe transport and storage has achieved a more significant endosperm Fe increase in rice. The cooperative overexpression of AtIRT1, AtNAS1, and PvFER in rice plants can increase Fe concentration not only in brown rice but also in polished rice, with endosperm Fe reaching $10.46 \mathrm{mg} \mathrm{kg}^{-1}$, which seems more efficient than transgenic lines with a single gene insertion [124]. Similarly, the endosperm Fe concentration increased up to $55 \mathrm{mg} \mathrm{kg}^{-1}$ 
by the synergistic overexpression of OsNAS1 and HvNAAT in japonica rice [125]. Aung et al. (2013) overexpressed HvNAS1, OsYSL2 and soybean FER in rice varieties widely cultivated in Myanmar and Japan, and their Fe content in polished rice increased by 3.4 to 6 times, respectively [126].

Furthermore, genome editing methods have great potential for the bioreinforcement of micronutrients in rice. The latest genome editing tool is clustered regularly interspaced short palindromic repeats (CRISPR) for precise modifications, which provides the possibility of precise targeting genes or genomic regions. Knockdown of the OsVIT2 gene based on the CRISPR method can increase the Fe amount in grains [119]. The development of RNAimediated gene silencing technology has led to studies being conducted to reduce inositol 1,3,4,5,6-pentakisphosphate 2-kinase (IPK1) gene expression by RNAi [127]. In conclusion, important progress has been made in studies on implementing Fe bioreinforcement using genetic engineering, as summarized in (Table 1). As science and technology constantly evolve, more methods can be integrated into breeding and genetic engineering projects that target complex micronutrient biological reinforcement.

Table 1. Biofortification of Fe in rice using genetic engineering techniques.

\begin{tabular}{|c|c|c|c|c|}
\hline Gene & Method & Tissue & $\begin{array}{l}\text { Strengthen Fe } \\
\text { Level }\end{array}$ & Reference \\
\hline \multicolumn{5}{|l|}{ Absorption and transport } \\
\hline OsIRT1 & overexpression & brown rice & 1.1-fold & [52] \\
\hline OsYSL15 & overexpression & brown rice & 1.2-fold & [27] \\
\hline \multicolumn{5}{|l|}{ Long-distance transport } \\
\hline HvIDS3 & transgenic plant & polished rice & 1.4-fold & {$[117]$} \\
\hline OsYSL2 & overexpression & polished rice & 4.0-fold & {$[30]$} \\
\hline$u b i-1+H v Y S 1$ & constitutive expression & endosperm & 1.9-fold & {$[116]$} \\
\hline OsYSL9 & RNAi & embryo & ;.0-fold & [37] \\
\hline \multicolumn{5}{|l|}{ Storage protein } \\
\hline PyFER & transgene & brown rice & 2.0-fold & {$[113]$} \\
\hline GmFER & transgene & brown/polished rice & 3.0 3.7-fold & {$[56]$} \\
\hline SoyFER H1 & transgene & brown rice & 1.3-fold & {$[115]$} \\
\hline OsFER2 & overexpression & brown rice & 2.1-fold & {$[114]$} \\
\hline GmFER H1 & transgene & polished rice & 3.4-fold & [46] \\
\hline \multicolumn{5}{|l|}{$\begin{array}{l}\text { Vacuole-related } \\
\text { transport/storage }\end{array}$} \\
\hline OsVIT1/OsVIT2 & mutation & brown rice & 1.5-fold & {$[118]$} \\
\hline OsVIT2 & T-DNA insert & brown/polished rice & $>1.5$-fold & {$[109,120]$} \\
\hline OsVMT & knockout & polished rice & 1.8 2.1-fold & [121] \\
\hline \multicolumn{5}{|l|}{$\begin{array}{l}\text { Chelate synthase and } \\
\text { combination strategy }\end{array}$} \\
\hline OsNAS1/OsNAS2/OsNAS3 & overexpression & brown rice & 2.0 4.0-fold & {$[25,26]$} \\
\hline HvNAS1, OsYSL2, SoyFER & overexpression & polished rice & 3.4-fold & [126] \\
\hline AtIRT1, AtNAS1, PvFER & overexpression & endosperm & 4.2-fold & {$[124]$} \\
\hline OsNAS1, HvNAAT & overexpression & embryo/endosperm & 1.3 2.9-fold & [125] \\
\hline \multicolumn{5}{|l|}{ Transcription factor } \\
\hline OsIRO2 & overexpression & brown rice & 3.0-fold & {$[122]$} \\
\hline OsHRZ1/OsHRZ2 & knockout & brown/polished rice & 2.9 3.8-fold & [123] \\
\hline
\end{tabular}

\section{Suggestions for Further Research}

Human iron deficiency is a widespread and increasingly serious health problem, and the biological strengthening of Fe in staple food is an effective way to address and alleviate this problem. Fe-enriched varieties can be developed and promoted as functional foods or alternative staple foods to ensure that people have adequate daily sources of nutritional $\mathrm{Fe}$, particularly in developing countries that have rice as a staple food. According to the progress seen in the above research, the following suggestions are developed for future research directions and strategies for Fe biological strengthening in rice. 
First, traditional resources can be used to develop a variety of Fe-reinforced rice varieties to meet the needs of different agricultural ecosystems. Although the range of genetic variation in rice germplasm is not sufficient to achieve its Fe-rich targets, there is a degree of variation among different varieties that affects grain Fe concentrations. Originally, the Fe(III)-DMA transporter encoded by YSL18 was expressed in rice phloem and had a higher expression of YSL18 in flag leaves from Fe-enriched varieties compared to that of other ordinary varieties $[35,128]$. This suggests that the speed-limiting steps for increasing grain Fe concentration are also variety-specific. This discrepancy may manifest as different effects of certain biological reinforcement strategies under a genomic background. For different rice varieties, a restriction-factor analysis for their grain Fe levels, which are especially common as targets for biological reinforcement within geographic regions, will be useful to identify genetic germplasms suitable for biological reinforcement. Bioreinforcement strategies must also be tested in a growing number of common varieties that are widely planted worldwide to enter the application stage. Genetic variation is significant not only for rice Fe concentration but also to avoid the accumulation of toxic metals. Currently, although it is unclear whether Cd content in Fe-bioreinforced lines is affected, the main quantitative trait loci for the $\mathrm{Cd}$ content and the corresponding genomic markers have been identified. This knowledge would facilitate procedure screening against a Fe-rich variety background to reduce the risk of toxic metal accumulation $[129,130]$. The absorption of toxic metals, including $\mathrm{As}, \mathrm{Cd}, \mathrm{Hg}$, and $\mathrm{Pb}$, is known to be negatively correlated with Fe plaque formation on the root surface, which is caused by root oxygenation and differences with different genotypes in rice [131,132]. Therefore, to ensure that the roots of Fe-bioreinforced lines can still form enough Fe plaque to block toxic metal absorption, screening iron-fortified background cultivars from their root oxygenation capacity can be considered.

Genetic engineering is a more suitable biological reinforcement strategy to quickly break through the bottleneck or limit of improving grain-micronutrients in rice. For more than a decade, transgenic or gene-editing methods have been beneficial for rice nutrition biology reinforcement, including the efficient expression of Fe absorption, transport and accumulation of related genes, reduced competitive gene expression to improve Fe in rice, and improved ferritin bioutilization as well as synchronous multigene efficiency strategies, endosperm-specific reinforcement strategies, and collaborative micronutrient accumulation angles.

Although the molecular mechanisms of Fe homeostasis in rice have been gradually elucidated, the mechanistic complexity is not fully understood, and further molecular mechanisms will also contribute to the diversification of Fe biological reinforcement strategies. The type of rice that people eat is mostly polished refined rice, thus gene Fe biological reinforcement studies should consider the specific accumulation of Fe in tissue and especially the improvement of endosperm Fe concentration in order to meet the daily dietary needs. Among these priorities, the expression of genes involved in the long-distance transport of Fe and Fe storage, such as YSL, NAS and FER, are key to increasing endosperm Fe. The Fe bioavailability of rice is also one of the priorities of biological enhancement. The current in vitro assays based on Caco-2 cells and animal feeding experiments show that constitutive NAS expression or endosperm-specific FER is susceptible to intestinal absorption, but the study of Fe bioavailability is still in its primary stage. Therefore, future research on whether Fe-bioreinforced rice can improve the health of Fe-deficient people is the main focus, and in addition to the above strategies, strategies to improve bioavailability still need to be studied.

Second, the relationship between nutritional Fe-enriched characteristics, planting environments and genetic backgrounds should be emphasized, and cultivation-regulation means should be used to improve grain Fe quantities to accomplish nutritional biological strengthening. Environmental factors, such as Fe absorption and transportation mechanisms, water management, and soil $\mathrm{pH}$, the application amounts of nitrogen and phosphorus fertilizer, and even changes in atmospheric conditions, will affect Fe enrichment or 
reinforcement in rice. Water management controls the solubility of Fe from soil by affecting its redox potential, thus the rice grain effective Fe capacity is also affected. Therefore, different water management protocols can be formulated based on the variation in Fe absorption capacity of Fe-rich or Fe-reinforced transgenic rice lines. According to agronomic fertilization, the main problem is environmental pollution. Although most micronutrient fertilizers are not easy to leach, they combine firmly with the soil very easily, and the continuous use of trace nutrient fertilizer can lead to mineral accumulation, which can lead to toxic effects. Therefore, it is necessary to design and optimize fertilization measures. Among the measures, leaf fertilization is more environmentally friendly than soil fertilization is, which causes less pollution, but the cost of leaf fertilization is relatively high. Future research on foliar fertilizer needs to emphasize multiform and low-cost efficient fertilizer, and it can also consider the development of new nanoparticles combined with fertilizer to further improve the utilization efficiency.

\section{Concluding Remarks}

Over the past few decades, different Fe-trophic bioreinforcement strategies have been explored in rice, and some of these strategies have also been demonstrated to effectively improve grain Fe levels. Nevertheless, there are still challenges in food safety and nutritional effects. Therefore, both plant scientists and nutritionists should be involved in the study of nutritional biological reinforcement strategies, the promotion and application of food crops, nutritional utilization, and food safety.

Author Contributions: Q.W. wrote the original draft preparation. Q.W., M.C., and Q.H. carried out the investigation, resources, and data curation. H.Z. and Y.H. designed, reviewed and edited the manuscript. Y.H. made conceptualization, and applied for the project and supervision. All authors have read and agreed to the published version of the manuscript.

Funding: This work was supported by the National Natural Science Foundation of China (31801294). Institutional Review Board Statement: Not applicable.

Informed Consent Statement: Not applicable.

Data Availability Statement: All data are presented in the review manuscript in the form of tables and figures.

Conflicts of Interest: All authors declare that they have no competing interest.

\section{References}

1. World Health Organization. WHO Global Anaemia Estimates, 2021 Edition. Available online: https://www.who.int/data/gho/ data/themes/topics/anaemia_in_women_and_children (accessed on 10 November 2021).

2. Kulkarni, A.; Khade, M.; Arun, S.; Badami, P.; Kumar, G.R.K.; Dattaroy, T.; Soni, B.; Dasgupta, S. An overview on mechanism, cause, prevention and multi-nation policy level interventions of dietary iron deficiency. Crit. Rev. Food Sci. Nutr. 2021, 2, 1-15. [CrossRef] [PubMed]

3. Kawakami, Y.; Bhullar, N.K. Potential implications of interactions between Fe and S on cereal Fe biofortification. J. Integr. Plant Biol. 2020, 21, 2827. [CrossRef] [PubMed]

4. Maganti, S.; Swaminathan, R.; Parida, A. Variation in Iron and Zinc Content in Traditional Rice Genotypes. Agric. Res. 2020, 9 , 316-328. [CrossRef]

5. Broadley, M.; Brown, P.; Cakmak, I.; Rengel, Z.; Zhao, F. Function of Nutrients: Micronutrients. In Marschner's Mineral Nutrition of Higher Plants, 3rd ed.; Marschner, P., Ed.; Academic Press: San Diego, CA, USA, 2012; pp. 191-248. [CrossRef]

6. Stevens, G.A.; Finucane, M.M.; De-Regil, L.M.; Paciorek, C.J.; Flaxman, S.R.; Branca, F.; Peña-Rosas, J.P.; Bhutta, Z.A.; Ezzati, M. Global, regional, and national trends in haemoglobin concentration and prevalence of total and severe anaemia in children and pregnant and non-pregnant women for 1995-2011: A systematic analysis of population-representative data. Lancet Glob. Health 2013, 1, e16-e25. [CrossRef]

7. Briat, J.-F.; Dubos, C.; Gaymard, F. Iron nutrition, biomass production, and plant product quality. Trends Plant Sci. 2015, 20, 33-40. [CrossRef] [PubMed]

8. Muthayya, S.; Sugimoto, J.D.; Montgomery, S.; Maberly, G.F. An overview of global rice production, supply, trade, and consumption. Ann. N. Y. Acad. Sci. 2014, 1324, 7-14. [CrossRef] 
9. Kumar, A.; Lal, M.K.; Kar, S.S.; Nayak, L.; Ngangkham, U.; Samantaray, S.; Sharma, S.G. Bioavailability of iron and zinc as affected by phytic acid content in rice grain. J. Food Biochem. 2017, 41, e12413. [CrossRef]

10. Wei, Y.Y.; Wang, S.; Gu, M.H.; He, L.X.; Shen, F.K.; Cai, Z.Q. Genotypic Variations in Concentrations of Selenium, Iron and Zinc in Rice Grain and Its Dietary Exposure Assessment. Food Ind. 2020, 41, 217-220.

11. Shi, Y.M.; Liu, B.L.; Wang, W.H.; Zheng, T.Q.; Xu, J.L.; Wei, S.F.; Wu, H.; Liao, Z.B. Preliminary Report on the Screening of Functional Components of Fe, Zn and Se in Some Rice Germplasms and Rice Breeding Material. Seed 2019, 38, 75-77.

12. Lu, L.; Tian, S.; Liao, H.; Zhang, J.; Yang, X.; Labavitch, J.M.; Chen, W. Analysis of Metal Element Distributions in Rice (Oryza sativa L.) Seeds and Relocation during Germination Based on X-Ray Fluorescence Imaging of Zn, Fe, K, Ca, and Mn. PLoS ONE 2013, 8, e57360. [CrossRef]

13. Trumbo, P.; Yates, A.A.; Schlicker, S.; Poos, M. Dietary Reference Intakes: Vitamin A, Vitamin K, Arsenic, Boron, Chromium, Copper, Iodine, Iron, Manganese, Molybdenum, Nickel, Silicon, Vanadium, and Zinc. J. Am. Diet. Assoc. 2001, 101, 294-301. [CrossRef]

14. Sohn, E. Contamination: The toxic side of rice. Nature 2014, 514, S62-S63. [CrossRef] [PubMed]

15. Bouis, H.E.; Hotz, C.; McClafferty, B.; Meenakshi, J.V.; Pfeiffer, W.H. Biofortification: A New Tool to Reduce Micronutrient Malnutrition. Food Nutr. Bull. 2011, 32, S31-S40. [CrossRef] [PubMed]

16. Kobayashi, T.; Nakanishi, H.; Nishizawa, N.K. Recent insights into iron homeostasis and their application in graminaceous crops. Proc. Jpn. Acad. Ser. B Phys. Biol. Sci. 2010, 86, 900-913. [CrossRef] [PubMed]

17. Kobayashi, T.; Nishizawa, N.K. Iron Uptake, Translocation, and Regulation in Higher Plants. Annu. Rev. Plant Biol. 2012, 63, 131-152. [CrossRef]

18. Ishimaru, Y.; Suzuki, M.; Tsukamoto, T.; Suzuki, K.; Nakazono, M.; Kobayashi, T.; Wada, Y.; Watanabe, S.; Matsuhashi, S.; Takahashi, M.; et al. Rice plants take up iron as an $\mathrm{Fe}^{3+}$-phytosiderophore and as $\mathrm{Fe}^{2+}$. Plant J. 2006, 45, 335-346. [CrossRef]

19. Vert, G.; Grotz, N.; Dédaldéchamp, F.; Gaymard, F.; Guerinot, M.L.; Briat, J.F.; Curie, C. Correction: IRT1, an arabidopsis transporter essential for iron uptake from the soil and for plant growth. Plant Cell 2021, 33, 439-440. [CrossRef] [PubMed]

20. Takahashi, R.; Ishimaru, Y.; Senoura, T.; Shimo, H.; Ishikawa, S.; Arao, T.; Nakanishi, H.; Nishizawa, N.K. The OsNRAMP1 iron transporter is involved in Cd accumulation in rice. J. Exp. Bot. 2011, 62, 4843-4850. [CrossRef]

21. Ishimaru, Y.; Bashir, K.; Nakanishi, H.; Nishizawa, N.K. OsNRAMP5, a major player for constitutive iron and manganese uptake in rice. Plant Signal Behav. 2012, 7, 763-766. [CrossRef] [PubMed]

22. Cesco, S.; Neumann, G.; Tomasi, N.; Pinton, R.; Weisskopf, L. Release of plant-borne flavonoids into the rhizosphere and their role in plant nutrition. Plant Soil 2010, 329, 1-25. [CrossRef]

23. Ishimaru, Y.; Kakei, Y.; Shimo, H.; Bashir, K.; Sato, Y.; Sato, Y.; Uozumi, N.; Nakanishi, H.; Nishizawa, N.K. A Rice Phenolic Efflux Transporter Is Essential for Solubilizing Precipitated Apoplasmic Iron in the Plant Stele. J. Biol. Chem. 2011, 286, 24649-24655. [CrossRef] [PubMed]

24. Inoue, H.; Higuchi, K.; Takahashi, M.; Nakanishi, H.; Mori, S.; Nishizawa, N.K. Three rice nicotianamine synthase genes, OsNAS1, OsNAS2, and OsNAS3 are expressed in cells involved in long-distance transport of iron and differentially regulated by iron. Plant J. 2003, 36, 366-381. [CrossRef] [PubMed]

25. Johnson, A.A.T.; Kyriacou, B.; Callahan, D.L.; Carruthers, L.; Stangoulis, J.; Lombi, E.; Tester, M. Constitutive Overexpression of the OsNAS Gene Family Reveals Single-Gene Strategies for Effective Iron- and Zinc-Biofortification of Rice Endosperm. PLoS ONE 2011, 6, e24476. [CrossRef] [PubMed]

26. Lee, S.; Kim, Y.-S.; Jeon, U.S.; Kim, Y.-K.; Schjoerring, J.K.; An, G. Activation of Rice nicotianamine synthase 2 (OsNAS2) enhances iron availability for biofortification. Mol. Cells 2012, 33, 269-275. [CrossRef] [PubMed]

27. Lee, S.; Chiecko, J.C.; Kim, S.A.; Walker, E.L.; Lee, Y.; Guerinot, M.L.; An, G. Disruption of OsYSL15 Leads to Iron Inefficiency in Rice Plants. Plant Physiol. 2009, 150, 786-800. [CrossRef] [PubMed]

28. Kakei, Y.; Ishimaru, Y.; Kobayashi, T.; Yamakawa, T.; Nakanishi, H.; Nishizawa, N.K. OsYSL16 plays a role in the allocation of iron. Plant Mol. Biol. 2012, 79, 583-594. [CrossRef] [PubMed]

29. Roschzttardtz, H.; Conéjéro, G.; Divol, F.; Alcon, C.; Verdeil, J.-L.; Curie, C.; Mari, S. New insights into Fe localization in plant tissues. Front. Plant Sci. 2013, 4, 350. [CrossRef]

30. Ishimaru, Y.; Masuda, H.; Bashir, K.; Inoue, H.; Tsukamoto, T.; Takahashi, M.; Nakanishi, H.; Aoki, N.; Hirose, T.; Ohsugi, R.; et al. Rice metal-nicotianamine transporter, OsYSL2, is required for the long-distance transport of iron and manganese. Plant J. 2010, 62, 379-390. [CrossRef] [PubMed]

31. Nishiyama, R.; Kato, M.; Nagata, S.; Yanagisawa, S.; Yoneyama, T. Identification of Zn-Nicotianamine and Fe-2'-Deoxymugineic Acid in the Phloem Sap from Rice Plants (Oryza sativa L.). Plant Cell Physiol. 2012, 53, 381-390. [CrossRef] [PubMed]

32. Yokosho, K.; Yamaji, N.; Ueno, D.; Mitani, N.; Ma, J.F. OsFRDL1 Is a Citrate Transporter Required for Efficient Translocation of Iron in Rice. Plant Physiol. 2008, 149, 297-305. [CrossRef]

33. Bonneau, J.; Baumann, U.; Beasley, J.; Li, Y.; Johnson, A.A.T. Identification and molecular characterization of the nicotianamine synthase gene family in bread wheat. Plant Biotechnol. J. 2016, 14, 2228-2239. [CrossRef]

34. Inoue, H.; Kobayashi, T.; Nozoye, T.; Takahashi, M.; Kakei, Y.; Suzuki, K.; Nakazono, M.; Nakanishi, H.; Mori, S.; Nishizawa, N.K. Rice OsYSL15 Is an Iron-regulated Iron(III)-Deoxymugineic Acid Transporter Expressed in the Roots and Is Essential for Iron Uptake in Early Growth of the Seedlings. J. Biol. Chem. 2009, 284, 3470-3479. [CrossRef] [PubMed] 
35. Aoyama, T.; Kobayashi, T.; Takahashi, M.; Nagasaka, S.; Usuda, K.; Kakei, Y.; Ishimaru, Y.; Nakanishi, H.; Mori, S.; Nishizawa, N.K. OsYSL18 is a rice iron (III)-deoxymugineic acid transporter specifically expressed in reproductive organs and phloem of lamina joints. Plant Mol. Biol. 2009, 70, 681-692. [CrossRef]

36. Koike, S.; Inoue, H.; Mizuno, D.; Takahashi, M.; Nakanishi, H.; Mori, S.; Nishizawa, N.K. OsYSL2 is a rice metal-nicotianamine transporter that is regulated by iron and expressed in the phloem. Plant J. 2004, 39, 415-424. [CrossRef] [PubMed]

37. Senoura, T.; Sakashita, E.; Kobayashi, T.; Takahashi, M.; Aung, M.S.; Masuda, H.; Nakanishi, H.; Nishizawa, N.K. The iron-chelate transporter OsYSL9 plays a role in iron distribution in developing rice grains. Plant Mol. Biol. 2017, 95, 375-387. [CrossRef] [PubMed]

38. Prom-u-Thai, C.; Dell, B.; Thomson, G.; Rerkasem, B. Easy and rapid detection of iron in rice grain. ScienceAsia 2003, 29 , $203-207$. [CrossRef]

39. Wang, K.M.; Wu, J.G.; Li, G.; Zhang, D.P.; Yang, Z.W.; Shi, C.H. Distribution of phytic acid and mineral elements in three indica rice (Oryza sativa L.) cultivars. J. Cereal Sci. 2011, 54, 116-121. [CrossRef]

40. Radchuk, V.; Weier, D.; Radchuk, R.; Weschke, W.; Weber, H. Development of maternal seed tissue in barley is mediated by regulated cell expansion and cell disintegration and coordinated with endosperm growth. J. Exp. Bot. 2010, 62, 1217-1227. [CrossRef] [PubMed]

41. Weber, G.; von Wirén, N.; Hayen, H. Investigation of ascorbate-mediated iron release from ferric phytosiderophores in the presence of nicotianamine. Biometals 2008, 21, 503-513. [CrossRef] [PubMed]

42. Ariga, T.; Hazama, K.; Yanagisawa, S.; Yoneyama, T. Chemical forms of iron in xylem sap from graminaceous and nongraminaceous plants. Soil Sci. Plant Nutr. 2014, 60, 460-469. [CrossRef]

43. Moore, K.L.; Zhao, F.-J.; Gritsch, C.S.; Tosi, P.; Hawkesford, M.J.; McGrath, S.P.; Shewry, P.R.; Grovenor, C.R.M. Localisation of iron in wheat grain using high resolution secondary ion mass spectrometry. J. Cereal Sci. 2012, 55, 183-187. [CrossRef]

44. Theil, E.C. Iron, Ferritin, and Nutrition. Annu. Rev. Nutr. 2004, 24, 327-343. [CrossRef] [PubMed]

45. Stein, R.J.; Ricachenevsky, F.K.; Fett, J.P. Differential regulation of the two rice ferritin genes (OsFER1 and OsFER2). Plant Sci. 2009, 177, 563-569. [CrossRef]

46. Oliva, N.; Chadha-Mohanty, P.; Poletti, S.; Abrigo, E.; Atienza, G.; Torrizo, L.; Garcia, R.; Dueñas, C.; Poncio, M.A.; Balindong, J.; et al. Large-scale production and evaluation of marker-free indica rice IR64 expressing phytoferritin genes. Mol. Breed. 2014, 33, 23-37. [CrossRef] [PubMed]

47. Kyriacou, B.; Moore, K.L.; Paterson, D.; de Jonge, M.D.; Howard, D.L.; Stangoulis, J.; Tester, M.; Lombi, E.; Johnson, A.A.T. Localization of iron in rice grain using synchrotron $\mathrm{X}$-ray fluorescence microscopy and high resolution secondary ion mass spectrometry. J. Cereal Sci. 2014, 59, 173-180. [CrossRef]

48. Foster, A.W.; Osman, D.; Robinson, N.J. Metal Preferences and Metallation. J. Biol. Chem. 2014, 289, 28095-28103. [CrossRef] [PubMed]

49. Briat, J.-F.; Rouached, H.; Tissot, N.; Gaymard, F.; Dubos, C. Integration of P, S, Fe, and Zn nutrition signals in Arabidopsis thaliana: Potential involvement of Phosphate Starvation Response 1 (PHR1). Front. Plant Sci. 2015, 6, 290. [CrossRef] [PubMed]

50. Kobayashi, T.; Nozoye, T.; Nishizawa, N.K. Iron transport and its regulation in plants. Free. Radic. Biol. Med. 2019, 133, 11-20. [CrossRef]

51. Shanmugam, V.; Lo, J.-C.; Yeh, K.-C. Control of Zn uptake in Arabidopsis halleri: A balance between Zn and Fe. Front. Plant Sci. 2013, 4, 281. [CrossRef] [PubMed]

52. Lee, S.; An, G. Over-expression of OsIRT1 leads to increased iron and zinc accumulations in rice. Plant Cell Environ. 2009, 32, 408-416. [CrossRef]

53. Yang, M.; Zhang, Y.; Zhang, L.; Hu, J.; Zhang, X.; Lu, K.; Dong, H.; Wang, D.; Zhao, F.-J.; Huang, C.-F.; et al. OsNRAMP5 contributes to manganese translocation and distribution in rice shoots. J. Exp. Bot. 2014, 65, 4849-4861. [CrossRef] [PubMed]

54. Mani, A.; Sankaranarayanan, K. In Silico Analysis of Natural Resistance-Associated Macrophage Protein (NRAMP) Family of Transporters in Rice. Protein J. 2018, 37, 237-247. [CrossRef] [PubMed]

55. Haydon, M.J.; Cobbett, C.S. Transporters of ligands for essential metal ions in plants. New Phytol. 2007, 174, 499-506. [CrossRef] [PubMed]

56. Vasconcelos, M.; Datta, K.; Oliva, N.; Khalekuzzaman, M.; Torrizo, L.; Krishnan, S.; Oliveira, M.; Goto, F.; Datta, S.K. Enhanced iron and zinc accumulation in transgenic rice with the ferritin gene. Plant Sci. 2003, 164, 371-378. [CrossRef]

57. Suzuki, M.; Tsukamoto, T.; Inoue, H.; Watanabe, S.; Matsuhashi, S.; Takahashi, M.; Nakanishi, H.; Mori, S.; Nishizawa, N.K. Deoxymugineic acid increases Zn translocation in Zn-deficient rice plants. Plant Mol. Biol. 2008, 66, 609-617. [CrossRef]

58. Lee, S.; Jeon, U.S.; Lee, S.J.; Kim, Y.-K.; Persson, D.P.; Husted, S.; Schjørring, J.K.; Kakei, Y.; Masuda, H.; Nishizawa, N.K.; et al. Iron fortification of rice seeds through activation of the nicotianamine synthase gene. Proc. Natl. Acad. Sci. USA 2009, 106, 22014-22019. [CrossRef] [PubMed]

59. Masuda, H.; Usuda, K.; Kobayashi, T.; Ishimaru, Y.; Kakei, Y.; Takahashi, M.; Higuchi, K.; Nakanishi, H.; Mori, S.; Nishizawa, N.K. Overexpression of the Barley Nicotianamine Synthase Gene HvNAS1 Increases Iron and Zinc Concentrations in Rice Grains. Rice 2009, 2, 155-166. [CrossRef]

60. Masuda, H.; Ishimaru, Y.; Aung, M.S.; Kobayashi, T.; Kakei, Y.; Takahashi, M.; Higuchi, K.; Nakanishi, H.; Nishizawa, N.K. Iron biofortification in rice by the introduction of multiple genes involved in iron nutrition. Sci. Rep. 2012, 2, 543. [CrossRef] 
61. Trijatmiko, K.R.; Dueñas, C.; Tsakirpaloglou, N.; Torrizo, L.; Arines, F.M.; Adeva, C.; Balindong, J.; Oliva, N.; Sapasap, M.V.; Borrero, J.; et al. Biofortified indica rice attains iron and zinc nutrition dietary targets in the field. Sci. Rep. 2016, 6, 19792. [CrossRef] [PubMed]

62. Gao, L.; Chang, J.; Chen, R.; Li, H.; Lu, H.; Tao, L.; Xiong, J. Comparison on cellular mechanisms of iron and cadmium accumulation in rice: Prospects for cultivating Fe-rich but Cd-free rice. Rice 2016, 9, 39. [CrossRef]

63. Bashir, A.; Rizwan, M.; Ali, S.; Zia ur Rehman, M.; Ishaque, W.; Atif Riaz, M.; Maqbool, A. Effect of foliar-applied iron complexed with lysine on growth and cadmium (Cd) uptake in rice under Cd stress. Environ. Sci. Pollut. Res. 2018, 25, 20691-20699. [CrossRef] [PubMed]

64. Han, Y.; Ling, Q.; Dong, F.; de Dios, V.R.; Li, Z.; Zhang, W.; Huo, T.; Chen, Y.; Hu, X.; Wang, X.; et al. Iron and copper micronutrients influences cadmium accumulation in rice grains by altering its transport and allocation. Sci. Total Environ. 2021, 777, 146118. [CrossRef]

65. Rizwan, M.; Ali, S.; Abbas, T.; Zia-ur-Rehman, M.; Hannan, F.; Keller, C.; Al-Wabel, M.I.; Ok, Y.S. Cadmium minimization in wheat: A critical review. Ecotoxicol. Environ. Saf. 2016, 130, 43-53. [CrossRef] [PubMed]

66. Wang, L.; Liu, B.; Wang, Y.; Qin, Y.; Zhou, Y.; Qian, H. Influence and interaction of iron and lead on seed germination in upland rice. Plant Soil 2020, 455, 187-202. [CrossRef]

67. Astolfi, S.; Pii, Y.; Terzano, R.; Mimmo, T.; Celletti, S.; Allegretta, I.; Lafiandra, D.; Cesco, S. Does Fe accumulation in durum wheat seeds benefit from improved whole-plant sulfur nutrition? J. Cereal Sci. 2018, 83, 74-82. [CrossRef]

68. Wu, Z.; Zhang, C.; Dai, C.; Ge, Y. Sufficient sulfur supply promotes seedling growth, alleviates oxidation stress, and regulates iron uptake and translocation in rice. Biol. Plant 2015, 59, 788-792. [CrossRef]

69. Wu, Z.; Naveed, S.; Zhang, C.; Ge, Y. Adequate supply of sulfur simultaneously enhances iron uptake and reduces cadmium accumulation in rice grown in hydroponic culture. Environ. Pollut. 2020, 262, 114327. [CrossRef] [PubMed]

70. Zheng, L.; Huang, F.; Narsai, R.; Wu, J.; Giraud, E.; He, F.; Cheng, L.; Wang, F.; Wu, P.; Whelan, J.; et al. Physiological and Transcriptome Analysis of Iron and Phosphorus Interaction in Rice Seedlings. Plant Physiol. 2009, 151, 262-274. [CrossRef]

71. Rai, V.; Sanagala, R.; Sinilal, B.; Yadav, S.; Sarkar, A.K.; Dantu, P.K.; Jain, A. Iron Availability Affects Phosphate DeficiencyMediated Responses, and Evidence of Cross-Talk with Auxin and Zinc in Arabidopsis. Plant Cell Physiol. 2015, 56, 1107-1123. [CrossRef] [PubMed]

72. Valentinuzzi, F.; Venuti, S.; Pii, Y.; Marroni, F.; Cesco, S.; Hartmann, F.; Mimmo, T.; Morgante, M.; Pinton, R.; Tomasi, N.; et al. Common and specific responses to iron and phosphorus deficiencies in roots of apple tree (Malus $\times$ domestica). Plant Mol. Biol. 2019, 101, 129-148. [CrossRef]

73. Bournier, M.; Tissot, N.; Mari, S.; Boucherez, J.; Lacombe, E.; Briat, J.-F.; Gaymard, F. Arabidopsis Ferritin 1 (AtFer1) Gene Regulation by the Phosphate Starvation Response 1 (AtPHR1) Transcription Factor Reveals a Direct Molecular Link between Iron and Phosphate Homeostasis. J. Biol. Chem. 2013, 288, 22670-22680. [CrossRef] [PubMed]

74. Müller, J.; Gödde, V.; Niehaus, K.; Zörb, C. Metabolic Adaptations of White Lupin Roots and Shoots under Phosphorus Deficiency. Front. Plant Sci. 2015, 6, 1014. [CrossRef]

75. Dong, J.; Piñeros, M.A.; Li, X.; Yang, H.; Liu, Y.; Murphy, A.S.; Kochian, L.V.; Liu, D. An Arabidopsis ABC Transporter Mediates Phosphate Deficiency-Induced Remodeling of Root Architecture by Modulating Iron Homeostasis in Roots. Mol. Plant 2017, 10, 244-259. [CrossRef] [PubMed]

76. Godon, C.; Mercier, C.; Wang, X.; David, P.; Richaud, P.; Nussaume, L.; Liu, D.; Desnos, T. Under phosphate starvation conditions, Fe and Al trigger accumulation of the transcription factor STOP1 in the nucleus of Arabidopsis root cells. Plant J. 2019, 99, 937-949. [CrossRef] [PubMed]

77. Mora-Macías, J.; Ojeda-Rivera, J.O.; Gutiérrez-Alanís, D.; Yong-Villalobos, L.; Oropeza-Aburto, A.; Raya-González, J.; JiménezDomínguez, G.; Chávez-Calvillo, G.; Rellán-Álvarez, R.; Herrera-Estrella, L. Malate-dependent Fe accumulation is a critical checkpoint in the root developmental response to low phosphate. Proc. Natl. Acad. Sci. USA 2017, 114, E3563-E3572. [CrossRef] [PubMed]

78. Hanikenne, M.; Esteves, S.M.; Fanara, S.; Rouached, H. Coordinated homeostasis of essential mineral nutrients: A focus on iron. J. Exp. Bot. 2021, 72, 2136-2153. [CrossRef] [PubMed]

79. López-Bucio, J.S.; Salmerón-Barrera, G.J.; Ravelo-Ortega, G.; Raya-González, J.; León, P.; de la Cruz, H.R.; Campos-García, J.; López-Bucio, J.; Guevara-García, Á.A. Mitogen-activated protein kinase 6 integrates phosphate and iron responses for indeterminate root growth in Arabidopsis thaliana. Planta 2019, 250, 1177-1189. [CrossRef] [PubMed]

80. Ai, H.; Cao, Y.; Jain, A.; Wang, X.; Hu, Z.; Zhao, G.; Hu, S.; Shen, X.; Yan, Y.; Liu, X.; et al. The ferroxidase LPR5 functions in the maintenance of phosphate homeostasis and is required for normal growth and development of rice. J. Exp. Bot. 2020, 71, 4828-4842. [CrossRef] [PubMed]

81. Guo, M.; Ruan, W.; Zhang, Y.; Zhang, Y.; Wang, X.; Guo, Z.; Wang, L.; Zhou, T.; Paz-Ares, J.; Yi, K. A reciprocal inhibitory module for Pi and iron signaling. Mol. Plant 2021. [CrossRef] [PubMed]

82. Saenchai, C.; Bouain, N.; Kisko, M.; Prom-u-thai, C.; Doumas, P.; Rouached, H. The Involvement of OsPHO1;1 in the Regulation of Iron Transport Through Integration of Phosphate and Zinc Deficiency Signaling. Front. Plant Sci. 2016, 7, 396. [CrossRef] [PubMed] 
83. Garg, M.; Sharma, N.; Sharma, S.; Kapoor, P.; Kumar, A.; Chunduri, V.; Arora, P. Biofortified Crops Generated by Breeding, Agronomy, and Transgenic Approaches Are Improving Lives of Millions of People around the World. Front. Nutr. $2018,5,12$. [CrossRef] [PubMed]

84. Connorton, J.M.; Balk, J.; Rodríguez-Celma, J. Iron homeostasis in plants-a brief overview. Metallomics 2017, 9, 813-823. [CrossRef] [PubMed]

85. Anandan, A.; Rajiv, G.; Eswaran, R.; Prakash, M. Genotypic Variation and Relationships between Quality Traits and Trace Elements in Traditional and Improved Rice (Oryza sativa L.) Genotypes. J. Food Sci. 2011, 76, H122-H130. [CrossRef] [PubMed]

86. Palmgren, M.G.; Edenbrandt, A.K.; Vedel, S.E.; Andersen, M.M.; Landes, X.; Østerberg, J.T.; Falhof, J.; Olsen, L.I.; Christensen, S.B.; Sandøe, P.; et al. Are we ready for back-to-nature crop breeding? Trends Plant Sci. 2015, 20, 155-164. [CrossRef] [PubMed]

87. Descalsota, G.I.L.; Swamy, B.P.M.; Zaw, H.; Inabangan-Asilo, M.A.; Amparado, A.; Mauleon, R.; Chadha-Mohanty, P.; Arocena, E.C.; Raghavan, C.; Leung, H.; et al. Genome-Wide Association Mapping in a Rice MAGIC Plus Population Detects QTLs and Genes Useful for Biofortification. Front. Plant Sci. 2018, 9, 1347. [CrossRef] [PubMed]

88. Lu, K.; Li, L.; Zheng, X.; Zhang, Z.; Mou, T.; Hu, Z. Quantitative trait loci controlling Cu, Ca, Zn, Mn and Fe content in rice grains. J. Genet. 2008, 87, 305-310. [CrossRef] [PubMed]

89. Garcia-Oliveira, A.L.; Tan, L.; Fu, Y.; Sun, C. Genetic Identification of Quantitative Trait Loci for Contents of Mineral Nutrients in Rice Grain. J. Integr. Plant Biol. 2009, 51, 84-92. [CrossRef]

90. Norton, G.J.; Deacon, C.M.; Xiong, L.; Huang, S.; Meharg, A.A.; Price, A.H. Genetic mapping of the rice ionome in leaves and grain: Identification of QTLs for 17 elements including arsenic, cadmium, iron and selenium. Plant Soil 2010, 329, 139-153. [CrossRef]

91. Anuradha, K.; Agarwal, S.; Rao, Y.V.; Rao, K.V.; Viraktamath, B.C.; Sarla, N. Mapping QTLs and candidate genes for iron and zinc concentrations in unpolished rice of Madhukar $\times$ Swarna RILs. Gene 2012, 508, 233-240. [CrossRef]

92. Wu, X.-L.; Hu, Z.-L. Meta-analysis of QTL Mapping Experiments. In Quantitative Trait Loci (QTL): Methods and Protocols; Rifkin, S.A., Ed.; Humana Press: Totowa, NJ, USA, 2012; pp. 145-171. [CrossRef]

93. Swamy, B.P.M.; Kaladhar, K.; Anuradha, K.; Batchu, A.K.; Longvah, T.; Sarla, N. QTL Analysis for Grain Iron and Zinc Concentrations in Two O. nivara Derived Backcross Populations. Rice Sci. 2018, 25, 197-207. [CrossRef]

94. Fageria, N.K.; Baligar, V.C.; Clark, R.B. Micronutrients in Crop Production. In Advances in Agronomy; Sparks, D.L., Ed.; Academic Press: Cambridge, MA, USA, 2002; Volume 77, pp. 185-268.

95. El-Ramady, H.R.; Abdalla, N.; Fári, M.; Domokos-Szabolcsy, É. Selenium enriched vegetables as biofortification alternative for alleviating micronutrient malnutrition. Int. J. Hortic. Sci. 2014, 20, 75-81. [CrossRef]

96. Rehman, H.; Farooq, M.; Basra, S. High grain Zn content results from increased Zn supply and remobilization during grain filling in water saving rice cultivation. In Proceedings of the 14th Congress of Soil Science, Lahore, Pakistan, 12-15 March 2012; pp. 12-15.

97. Prasad, R.; Shivay, Y.S.; Kumar, D. Current Status, Challenges, and Opportunities in Rice Production. In Rice Production Worldwide; Chauhan, B.S., Jabran, K., Mahajan, G., Eds.; Springer International Publishing: Cham, Germany, 2017; pp. 1-32. [CrossRef]

98. Phattarakul, N.; Mongon, J.; Rerkasem, B. Variation in rice grain zinc and their response to zinc fertilizer. In Proceedings of the 3rd international zinc symposium, Hyderabad, India, 10-14 October 2011; pp. 10-14.

99. He, W.; Shohag, M.J.I.; Wei, Y.; Feng, Y.; Yang, X. Iron concentration, bioavailability, and nutritional quality of polished rice affected by different forms of foliar iron fertilizer. Food Chem. 2013, 141, 4122-4126. [CrossRef]

100. Yuan, L.; Wu, L.; Yang, C.; Lv, Q. Effects of iron and zinc foliar applications on rice plants and their grain accumulation and grain nutritional quality. J. Sci. Food Agric. 2013, 93, 254-261. [CrossRef] [PubMed]

101. Qiao, X.; He, Y.; Wang, Z.; Li, X.; Zhang, K.; Zeng, H. Effect of foliar spray of zinc on chloroplast $\beta$-carbonic anhydrase expression and enzyme activity in rice (Oryza sativa L.) leaves. Acta Physiol. Plant 2014, 36, 263-272. [CrossRef]

102. He, Y.; Luo, Y.; Wang, Q.; Sun, Y.; Duan, N.; Chen, Z.; Zeng, H. Spray treatment of leaves with Fe ${ }^{2+}$ promotes procyanidin biosynthesis by upregulating the expression of the F3H and ANS genes in red rice grains (Oryza sativa L.). J. Cereal Sci. 2021, 100, 103231. [CrossRef]

103. Das, P.; Barua, S.; Sarkar, S.; Karak, N.; Bhattacharyya, P.; Raza, N.; Kim, K.-H.; Bhattacharya, S.S. Plant extract-mediated green silver nanoparticles: Efficacy as soil conditioner and plant growth promoter. J. Hazard. Mater. 2018, 346, 62-72. [CrossRef]

104. Adisa, I.O.; Pullagurala, V.L.R.; Peralta-Videa, J.R.; Dimkpa, C.O.; Elmer, W.H.; Gardea-Torresdey, J.L.; White, J.C. Recent advances in nano-enabled fertilizers and pesticides: A critical review of mechanisms of action. Environ. Sci. Nano 2019, 6, 2002-2030. [CrossRef]

105. Li, M.; Zhang, P.; Adeel, M.; Guo, Z.; Chetwynd, A.J.; Ma, C.; Bai, T.; Hao, Y.; Rui, Y. Physiological impacts of zero valent iron, $\mathrm{Fe}_{3} \mathrm{O}_{4}$ and $\mathrm{Fe}_{2} \mathrm{O}_{3}$ nanoparticles in rice plants and their potential as Fe fertilizers. Environ. Pollut. 2021, 269, 116134. [CrossRef]

106. Qiao, J.-t.; Liu, T.-x.; Wang, X.-q.; Li, F.-b.; Lv, Y.-h.; Cui, J.-h.; Zeng, X.-d.; Yuan, Y.-z.; Liu, C.-p. Simultaneous alleviation of cadmium and arsenic accumulation in rice by applying zero-valent iron and biochar to contaminated paddy soils. Chemosphere 2018, 195, 260-271. [CrossRef] [PubMed]

107. Wu, F.; Fang, Q.; Yan, S.; Pan, L.; Tang, X.; Ye, W. Effects of zinc oxide nanoparticles on arsenic stress in rice (Oryza sativa L.): Germination, early growth, and arsenic uptake. Environ. Sci. Pollut. Res. 2020, 27, 26974-26981. [CrossRef] [PubMed]

108. Ghosh, I.; Mukherjee, A.; Mukherjee, A. In planta genotoxicity of nZVI: Influence of colloidal stability on uptake, DNA damage, oxidative stress and cell death. Mutagenesis 2017, 32, 371-387. [CrossRef] [PubMed] 
109. Bashir, K.; Takahashi, R.; Nakanishi, H.; Nishizawa, N. The road to micronutrient biofortification of rice: Progress and prospects. Front. Plant Sci. 2013, 4, 15. [CrossRef]

110. Vasconcelos, M.W.; Gruissem, W.; Bhullar, N.K. Iron biofortification in the 21st century: Setting realistic targets, overcoming obstacles, and new strategies for healthy nutrition. Curr. Opin. Biotechnol. 2017, 44, 8-15. [CrossRef]

111. Kawakami, Y.; Bhullar, N.K. Molecular processes in iron and zinc homeostasis and their modulation for biofortification in rice. J. Integr. Plant Biol. 2018, 60, 1181-1198. [CrossRef] [PubMed]

112. Mulualem, T. Application of bio-fortification through plant breeding to improve the value of staple crops. Biomed. Biotechnol. 2015, 3, 11-19. [CrossRef]

113. Lucca, P.; Hurrell, R.; Potrykus, I. Genetic engineering approaches to improve the bioavailability and the level of iron in rice grains. Theor. Appl. Genet. 2001, 102, 392-397. [CrossRef]

114. Paul, S.; Ali, N.; Gayen, D.; Datta, S.K.; Datta, K. Molecular breeding of Osfer2 gene to increase iron nutrition in rice grain. GM Crop. Food 2012, 3, 310-316. [CrossRef] [PubMed]

115. Qu, L.Q.; Yoshihara, T.; Ooyama, A.; Goto, F.; Takaiwa, F. Iron accumulation does not parallel the high expression level of ferritin in transgenic rice seeds. Planta 2005, 222, 225-233. [CrossRef] [PubMed]

116. Banakar, R.; Alvarez Fernández, Á.; Abadía, J.; Capell, T.; Christou, P. The expression of heterologous Fe (III) phytosiderophore transporter HvYS1 in rice increases Fe uptake, translocation and seed loading and excludes heavy metals by selective Fe transport. Plant Biotechnol. J. 2017, 15, 423-432. [CrossRef] [PubMed]

117. Suzuki, M.; Morikawa, K.C.; Nakanishi, H.; Takahashi, M.; Saigusa, M.; Mori, S.; Nishizawa, N.K. Transgenic rice lines that include barley genes have increased tolerance to low iron availability in a calcareous paddy soil. Soil Sci. Plant Nutr. 2008, 54, 77-85. [CrossRef]

118. Zhang, Y.; Xu, Y.-H.; Yi, H.-Y.; Gong, J.-M. Vacuolar membrane transporters OsVIT1 and OsVIT2 modulate iron translocation between flag leaves and seeds in rice. Plant J. 2012, 72, 400-410. [CrossRef]

119. Bashir, K.; Takahashi, R.; Akhtar, S.; Ishimaru, Y.; Nakanishi, H.; Nishizawa, N.K. The knockdown of OsVIT2 and MIT affects iron localization in rice seed. Rice 2013, 6, 31. [CrossRef] [PubMed]

120. Che, J.; Yamaji, N.; Ma, J.F. Role of a vacuolar iron transporter OsVIT2 in the distribution of iron to rice grains. New Phytol. 2021, 230, 1049-1062. [CrossRef] [PubMed]

121. Che, J.; Yokosho, K.; Yamaji, N.; Ma, J.F. A Vacuolar Phytosiderophore Transporter Alters Iron and Zinc Accumulation in Polished Rice Grains1. Plant Physiol. 2019, 181, 276-288. [CrossRef] [PubMed]

122. Ogo, Y.; Itai, R.N.; Kobayashi, T.; Aung, M.S.; Nakanishi, H.; Nishizawa, N.K. OsIRO2 is responsible for iron utilization in rice and improves growth and yield in calcareous soil. Plant Mol. Biol. 2011, 75, 593-605. [CrossRef] [PubMed]

123. Kobayashi, T.; Nagasaka, S.; Senoura, T.; Itai, R.N.; Nakanishi, H.; Nishizawa, N.K. Iron-binding haemerythrin RING ubiquitin ligases regulate plant iron responses and accumulation. Nat. Commun. 2013, 4, 2792. [CrossRef] [PubMed]

124. Boonyaves, K.; Wu, T.-Y.; Gruissem, W.; Bhullar, N.K. Enhanced Grain Iron Levels in Rice Expressing an Iron-Regulated Metal Transporter, Nicotianamine Synthase, and Ferritin Gene Cassette. Front. Plant Sci. 2017, 8, 130. [CrossRef]

125. Díaz-Benito, P.; Banakar, R.; Rodríguez-Menéndez, S.; Capell, T.; Pereiro, R.; Christou, P.; Abadía, J.; Fernández, B.; ÁlvarezFernández, A. Iron and Zinc in the Embryo and Endosperm of Rice (Oryza sativa L.) Seeds in Contrasting 2'-Deoxymugineic Acid/Nicotianamine Scenarios. Front. Plant Sci. 2018, 9, 1190. [CrossRef] [PubMed]

126. Aung, M.; Masuda, H.; Kobayashi, T.; Nakanishi, H.; Yamakawa, T.; Nishizawa, N. Iron Biofortification of Myanmar Rice. Front. Plant Sci. 2013, 4, 158. [CrossRef]

127. Ali, N.; Paul, S.; Gayen, D.; Sarkar, S.N.; Datta, K.; Datta, S.K. Development of Low Phytate Rice by RNAi Mediated Seed-Specific Silencing of Inositol 1,3,4,5,6-Pentakisphosphate 2-Kinase Gene (IPK1). PLoS ONE 2013, 8, e68161. [CrossRef]

128. Narayanan, N.N.; Vasconcelos, M.W.; Grusak, M.A. Expression profiling of Oryza sativa metal homeostasis genes in different rice cultivars using a cDNA macroarray. Plant Physiol. Biochem. 2007, 45, 277-286. [CrossRef] [PubMed]

129. Huang, X.-Y.; Zhao, F.-J. QTL pyramiding for producing nutritious and safe rice grains. J. Integr. Plant Biol. 2020, 62, 264-268. [CrossRef] [PubMed]

130. Liu, C.-L.; Gao, Z.-Y.; Shang, L.-G.; Yang, C.-H.; Ruan, B.-P.; Zeng, D.-L.; Guo, L.-B.; Zhao, F.-J.; Huang, C.-F.; Qian, Q. Natural variation in the promoter of OsHMA3 contributes to differential grain cadmium accumulation between Indica and Japonica rice. J. Integr. Plant Biol. 2020, 62, 314-329. [CrossRef] [PubMed]

131. Cheng, H.; Wang, M.; Wong, M.H.; Ye, Z. Does radial oxygen loss and iron plaque formation on roots alter $\mathrm{Cd}$ and $\mathrm{Pb}$ uptake and distribution in rice plant tissues? Plant Soil 2014, 375, 137-148. [CrossRef]

132. Li, Y.; Zhao, J.; Zhang, B.; Liu, Y.; Xu, X.; Li, Y.-F.; Li, B.; Gao, Y.; Chai, Z. The influence of iron plaque on the absorption, translocation and transformation of mercury in rice (Oryza sativa L.) seedlings exposed to different mercury species. Plant Soil 2016, 398, 87-97. [CrossRef] 